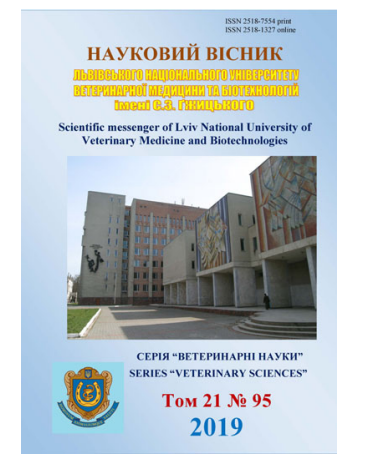

Науковий вісник Дьвівського націонадьного університету ветеринарної медицини та біотехнологій імені С.3. Гжицького. Серія: Ветеринарні науки

Scientific Messenger of Lviv National University of Veterinary Medicine and Biotechnologies. Series: Veterinary sciences

\title{
Parameters of chronic toxicity of the solution for intrauterine use "Yodozol"
}

\author{
R.M. Sachuk ${ }^{1}$, Ya.S. Stravsky ${ }^{2}$, O.A. Katsaraba ${ }^{3}$, S.V. Zhigalyuk ${ }^{1}$ \\ ${ }^{1}$ Research Epizootology Station IVM NAAS, Rivne, Ukraine \\ ${ }^{2}$ DVNZ "Ternopil State Medical University named after I.Ya. Gorbachevsky of the Ministry of Health of Ukraine”, \\ Ternopil, Ukraine \\ ${ }^{3}$ Stepan Gzhytskyi National University of Veterinary Medicine and Biotechnologies Lviv, Ukraine
}

\section{Article info}

Received 23.09.2019

Received in revised form 23.10.2019

Accepted 24.10.2019

Research Epizootology Station IVM NAAS, Knyaz Vladimir Str., 16/18,

33028, Rivne, Ukraine.

Tel.: +38-097-671-90-63

E-mail: sachuk.08@ukr.net

DVNZ "Ternopil State Medical University named after I. Ya. Gorbachevsky of the Ministry of Health of Ukraine", Ternopil, 46001, Ukraine.

Stepan Gzhytskyi National University of Veterinary Medicine and Biotechnologies Lviv, Pekarska Str., 50, Lviv, 79010, Ukraine. Tel.: +38-067-670-68-46 E-mail: Katsaraba@gmail.com
Sachuk, R.M., Stravsky, Ya.S., Katsaraba, O.A., \& Zhigalyuk, S.V. (2019). Parameters of chronic toxicity of the solution for intrauterine use "Yodozol". Scientific Messenger of Lviv National University of Veterinary Medicine and Biotechnologies. Series: Veterinary sciences, 21(95), 139_ 143. doi: $10.32718 /$ nvlvet9526

The study of the chronic toxicity of the solution for intrauterine use in the form of aerosol - "Yodosol", is a mandatory stage of preclinical study of the drug, which is a new development of PE «Biopharm» and the Experimental Station of epizootology of the Institute of Infectious Diseases of NAAN. In a scientific experiment on laboratory animals, it is possible to evaluate the safety of the drug at different times of use, to determine the area of toxic action and doses that do not cause adverse health effects. Therefore, the purpose of the study was to study the chronic toxicity of the drug "Yodosol", in particular the determination of tolerant and toxic doses for rodents. The experiments were carried out in accordance with the requirements for biomedical research, the selection of analogues for testing and control, ensuring the same conditions of feeding and retention, as well as accounting for results. "Yodosol" is a light yellow foamy liquid with $1 \mathrm{ml}$ containing $5 \mathrm{mg}$ iodine and $10 \mathrm{mg}$ potassium iodide. The drug is used for the prevention and treatment of postpartum intrauterine infections in cows, pigs, sheep and goats (endometritis, pyrometers, cervicitis, vaginitis, delayed litter caused by iodine-sensitive microorganisms), after delivery of rhododerma, caesarean delivery and caesarean delivery. The drug has antimicrobial, anti-inflammatory and analgesic effects, improves proliferative processes in the tissues of the genital organs, helps to reduce the time of recovery of animals. The drug is used according to the guideline, after its livestock products are used without restrictions. No significant deviations in the behavior of the experimental animals were observed in the studies of chronic toxicity of the drug "Yodosol". Visually noted only a slight inhibition of the rats of the experimental group, which received a 10-fold overdose. According to biochemical studies, in the group, compared with the control animals, there was a slight deviation of the indicators of protein metabolism and activity of hepatospecific enzymes: growth of total protein, alkaline phosphatase and aspartateaminotransferase. However, such changes in the blood parameters of the experimental animals were short-lived and restorative, characterizing the study drug as low-toxic. All studies conducted to determine the parameters of chronic toxicity of the solution for intrauterine use of "Yodosol" included in the registration materials of the medicinal product.

Key words: Yodine, potassium yodide, dose, blood, hematology, biochemistry, calving, service period, "Yodozole".

\section{Параметри хронічної токсичності розчину для внутрішньоматкового застосування "Йодозол"}

Р.М. Сачук ${ }^{1}$, Я.С. Стравський², О.А. Кацараба ${ }^{3}$, С.В. Жигалюк ${ }^{1}$

${ }^{1}$ Дослідна станиія епізоотології ІВМ НААН, м. Рівне, Україна

${ }^{2}$ Тернопільський наиіональний медичний університет імені І.Я. Горбачевського МОЗ Украӥни, м. Тернопіль, Україна 
3.Львівський національний університет ветеринарної медицини та біотехнологій імені. С.3. Гљицького, м. Львів, Украӥна

Вивчення хронічної токсичності розчину для внутрішньоматкого застосування у вигляді аерозолю - “Йодозол”, обов’язковим етапом доклінічного дослідження препарату, щзо є новою розробкою ПП “Біофарм” та Дослідної станиії епізоотологї ІВМ НААН. У науковому експерименті на лабораторних тварин можливо оцінити безпечність препарату за різних термінів застосування, визначити зону токсичної дї та дози, які не викликають шкідливих ефектів для здоров'я. Тому метою роботи було вивчення хронічної токсичності лікарського засобу “Йодозол”, зокрема визначення толерантних $і$ токсичних доз для гризунів. Експерименти проведені відповідно до вимог до лікарсько-біологічних досліджень щодо підбору аналогів для досліду і контролю, забезпечення однакових умов годівлі та утримання, а також обліку результатів. “Йодозол” - спінена рідина світло-жовтого кольору, 1 мл якої містить 5 мг йоду та 10 мг калію йодиду. Препарат застосовують для профілактики та лікування післяродових внутрішньоматкових інфекцій у корів, свиней, овець $і$ кіз (ендометритів, пірометри, цервіцитів, вагінітів, затримки посліду, спричинених чутливими до йоду мікроорганізмами), після надання рододопомоги, кесаревого розтину та післяродової санації матки. Лікарський засіб володіє протимікробною, протизапальною та знеболювальною дією, поліпшує проліферативні процеси у тканинах статевих органів, сприяє скороченню термінів одужання тварин. Препарат застосовують згідно з настановами, після його продукиію тваринництва використовують без обмежень. У ході досліджень хронічної токсичності препарату “Йодозол” суттєвих відхилень у поведінці дослідних тварин не спостерігали. Візуально відзначали лише незначне пригнічення стану організму щурів дослідної групи, які одержували 10-кратно завищену дозу препарату. За даними біохімічних досліджень, у групі, порівняно з контрольними тваринами, виявляли незначні відхилення показників білкового обміну та активності гепатоспецифічних ферментів: зростання загального білка, лужної фосфатази та аспартатамінотрансферази. Однак такі зміни параметрів крові піддослідних тварин мали короткотривалий та відновлювальний характер, щьо характеризує досліджуваний препарат як малотоксичний. Усі проведені дослідження щзодо визначення параметрів хронічної токсичності розчину для внутрішньо маткового застосування “Йодозол” увійшли до реєстраційних матеріалів лікарського засобу.

Ключові слова: йод, калію йодид, доза, кров, гематологія, біохімія, токсичність, “Йодозол”.

\section{Вступ}

Однією з актуальних проблем сучасної ветеринарної фармакології є розробка надійних засобів профілактики післяродових інфекцій у корів шляхом створення вітчизняних, ефективних, пристосованих до конкретних фізіологічних аспектів організму тварини препаратів. Серед вимог до нових лікарських засобів головними є біоцидна дія на найширший спектр мікрофлори метроаспірату, зручність препаративної форми та безпечність отриманої тваринницької продукції - використання антимікробних речовин, що не виділяються $з$ молоком (Stravsky, 2017; Katsaraba et al., 2018).

Пошукам новітніх терапевтичних схем та розробці лікувально-профілактичних засобів для корів із акушерською патологією приділяється значна увага як вітчизняних так і зарубіжних дослідників. Нині після отелу використовують протимікробні та протизапальні препарати. Нажаль, стандартні схеми тривалого застосування сучасних антимікробних препаратів не завжди забезпечують достатній терапевтичний ефект, часто призводять до резистентності мікроорганізмів, інколи стимулюють розвиток мікроміцетів, пригнічують окремі природні механізми локального і загального антимікробного захисту. Також варто враховувати, що утворення складок на слизовій матці після родів знижує ефективність дії супозиторіїв, які широко використовуються у ветеринарній практиці, не гарантує рівномірного розподілу антимікробних речовин в порожнині матки, а отже повної іiі санації. Тому для лікування післяродових інфекцій у тварин краще застосовувати високоефективні антибіотики нових поколінь (наприклад, цефалоспорини) або йодовмісні препарати у різних препаративних формах (Sachuk et al., 2017; 2018).

Перспективним $є$ застосування нової розробки ПП “Біофарм" та Дослідної станцією епізоотології ІВМ
НААН - аерозольного внутрішньоматкового препарату “Йодозол", до складу якого входить йод та калію йодид. Застосовують препарат для профілактики та лікування післяродових внутрішньоматкових інфекцій у корів, свиней, овець і кіз (ендометритів, пірометри, цервіцитів, вагінітів, спричинених чутливими до йоду мікроорганізмами), після надання рододопомоги, кесаревого розтину, лікування затримки посліду, післяродової санації матки.

Обов'язковою умовою реєстрації нових лікарських препаратів $є$ попередні доклінічні дослідження на лабораторних тваринах, а зокрема визначення хронічної токсичності, що визначає характер та вираженість можливої шкідливої дії лікувального препарату на організм піддослідних об’єктів (Kosenko et al., 1997; Kotsyumbas et al., 2006).

Метою роботи було вивчення хронічної токсичності аерозольного внутрішньоматкового препарату “Йодозол", зокрема виявлення можливої шкідливої дії препарату за довготривалого введення в організм білих щурів.

\section{Матеріал і методи досліджень}

Експериментальна частина роботи проводилася на тваринах віварію Дослідної станції епізоотології IBM НААН, що перебували, відповідно до вимог санітарно-гігієнічних норм, на стандартному раціоні та отримували їжу і воду - ad libitum. Усі експерименти проводили керуючись виданнями “Доклінічні дослідження ветеринарних лікарських засобів" та "Методические указания по токсикологической оценке химических веществ и фармакологических препаратов применяемых в ветеринарии". Тварини перебували в кімнаті для проведення випробувань, у стандартних клітках, за природного світлового режиму “день-ніч", при $\mathrm{t}^{\circ}=20-25{ }^{\circ} \mathrm{C}$, вологості не більше ніж 55\%. В основі харчового раціону були гранульовані корми 
згідно з посібником “Науково-практичні рекомендації 3 утримання лабораторних тварин” (1983). 3 піддослідними поводились згідно з правилами “Європейської конвенції по захисту хребетних тварин, яких використовують для експериментальних та наукових цілей” (Страсбург, 1986 р).

Статистичну обробку отриманих результатів здійснено методами варіаційної статистики за допомогою стандартних пакетів програм Excel на персональному комп'ютері Pentium III. При порівнянні результатів між двома групами використовували модифікований параметричний t-критерій Стьюдента для виборок 3 нерівними дисперсіями.

При проведенні довготривалого досліду щодо вивчення хронічної токсичності білим щурам щодня внутрішньошлунково вводився досліджуваний препарат “Йодозол" у різних дозах. Було сформовано 4 групи тварин-аналогів, однакових за кількістю $(\mathrm{n}=15)$ та масою тіла (180-190 г). Контрольній групі тварин препарат не задавали. Іншим дослідним групам (Д1, Д2, Д $)$ задавали лікарський засіб відповідно у терапевтичній - 0,1 мл/кг живої маси тіла, 5-кратній та 10-кратній дозах. У експерименті використано препарат без пропелентів. За тваринами проводили щоденне спостереження протягом 30 діб. Клінічний стан оцінювали за наявністю апетиту, станом волосяного покриву і слизових оболонок, поведінковими реакціями, руховою активністю. На 30-ту добу від початку введення препарату на 7 щурах із кожної групи провели визначення дезінтоксикуючої функції печінки за допомогою гексеналової проби (Rozyn, 1964). Для цього тваринам вводили внутрішньоочеревинно1\% розчин гексеналу в дозі 45 мг/кг. Середній час сну реєстрували від моменту, коли тварина займала бокове положення.

Одночасно на інших 8 щурах проводили пробу 3 плаванням за M.L. Rylovoiu, 1964. Для проведення досліду використовували скляний акваріум, зі стовпом води - 50 см. Температура води $-12-13{ }^{\circ} \mathrm{C}$. Перед початком досліду щура зважували та прикріплю- вали на хвіст відповідний до його ваги вантажметалеві наважки, що складали 5\% від маси тіла. Потім пускали плавати одночасно дослідних і контрольних тварин, відсортованих за вагою. Слідкували, щоб тварини постійно плавали. Показником працездатності був час, упродовж якого тварина могла протриматися на воді, до повного опускання на дно (Gutyj, 2014; Gutyj et al., 2016; Todoriuk et al., 2018).

На 31-шу добу досліджень провели евтаназію щурів легким ефірним наркозом, здійснюючи при цьому забір крові для гематологічних і біохімічних досліджень. Також піддослідних гризунів розтинали і визначали коефіцієнти маси органів, порівнюючи 3 контрольною групою.

У крові досліджували концентрацію гемоглобіну, кількість еритроцитів і лейкоцитів, величину гематокриту за загальноприйнятими методами. Активність аланінамінотрансферази (АлАТ), аспартатамінотрансферази (АсАТ), лужної фосфатази (ЛФ), а також вміст загального білка, сечовини та глюкози в сироватці крові визначали за допомогою біохімічного аналізатора Cobas c 311.

Статистичну обробку результатів проводили за загальноприйнятою біометричною методикою (Lakin, 1990). Різницю між двома середніми величинами вважали статистично вірогідною при ${ }^{*}-\mathrm{P}<0,05$; ${ }^{* *}-\mathrm{P}<0,01 ;{ }^{* * *}-\mathrm{P}<0,001$.

\section{Результати та їх обговорення}

Відхилень у поведінці дослідних тварин упродовж періоду досліджень (31 доба) із визначення хронічної токсичності препарату "Йодозол" не спостерігали. Загиблих лабораторних тварин у всіх групах не зареєстровано. Результати гексеналової проби і тесту 3 плаванням, що були проведені по закінченні введення препарату, показали статистично вірогідне збільшення часу сну з одночасним зменшенням середнього часу плавання у тварин третьої дослідної групи (табл. 1).

\section{Таблиця 1}

Результати проведення функціональних проб, $\mathrm{M} \pm \mathrm{m}, \mathrm{n}=15$

\begin{tabular}{cccc}
\hline \multirow{2}{*}{ Група тварин } & \multirow{2}{*}{ Доза препарату } & Гексеналова проба & Проба з плаванням \\
\cline { 3 - 4 } & & Середній час сну, хв & Середній час плавання, хв \\
\hline контрольна & - & $27,11 \pm 0,34$ & $12,95 \pm 0,13$ \\
$Д_{1}$ & терапевтична & $27,95 \pm 0,18$ & $12,17 \pm 0,07^{* * *}$ \\
Д$_{2}$ & 5 -кратна & $29,67 \pm 0,22^{* * *}$ & $11,55 \pm 0,17^{* * *}$ \\
Д $_{3}$ & 10 -кратна & $31,09 \pm 0,26^{* * *}$ & $10,21 \pm 0,22^{* * *}$ \\
Примітка: ${ }^{* * *}-\mathrm{P}<0,001$ & &
\end{tabular}

Дослідження нешкідливості препарату “Йодозол” були доповнені макроскопічним оглядом внутрішніх органів тварин, проведеним відразу після евтаназії. У піддослідних щурів не було виявлено відхилень від норми. Завершальним етапом стало морфологічне вивчення життєво важливих органів щурів: легенів, печінки, нирок, серця та селезінки. На 31-шу добу, при введенні “Йодозолу” у максимальному - у 10кратному дозуванні, відзначено, що на тлі незначного зменшення маси тіла дослідних щурів маса їхніх легень вірогідно зростала на 12,7\% (P < 0,001), а печінки - на 26,6\% (P <0,01), щодо тварин контрольної групи. Через короткий період відновлення (4-5 діб) маса печінки щурів 1-шої дослідної групи наближалася до маси тварин, які не отримували препарат (контрольна група) (табл. 2). 
Таблиця 2

Маса внутрішніх органів білих щурів на 31-у добу за вивчення хронічної токсичності “Йодозол”, $\mathrm{M} \pm \mathrm{m}, \mathrm{n}=15$

\begin{tabular}{ccccc}
\hline \multirow{2}{*}{ Внутрішні органи } & \multicolumn{4}{c}{ Група тварин / доза препарату } \\
\cline { 2 - 5 } & К (контроль) & Д $\left(\right.$ терапевтична) $_{2}$ & Д $_{2}(5$-кратна) & Дз $\left(10\right.$-кратна) $^{*}$ \\
\hline Легені & $8,05 \pm 0,03$ & $8,75 \pm 0,06^{* * *}$ & $8,50 \pm 0,05^{* * *}$ & $9,07 \pm 0,07^{* * *}$ \\
Печінка & $32,28 \pm 0,26$ & $33,34 \pm 0,45^{* *}$ & $38,74 \pm 0,27^{* * *}$ & $40,88 \pm 0,24^{* * *}$ \\
Нирка права & $3,15 \pm 0,03$ & $3,51 \pm 0,05$ & $3,66 \pm 0,05$ & $3,69 \pm 0,02$ \\
Нирка ліва & $3,42 \pm 0,04$ & $3,66 \pm 0,04^{* * *}$ & $3,67 \pm 0,03^{* * *}$ & $3,73 \pm 0,02^{* * *}$ \\
Серце & $3,24 \pm 0,02$ & $3,44 \pm 0,04^{* * *}$ & $3,37 \pm 0,04^{* *}$ & $3,39 \pm 0,04^{* * *}$ \\
Селезінка & $5,33 \pm 0,05$ & $4,91 \pm 0,04^{* * *}$ & $5,09 \pm 0,02^{* * *}$ & $5,61 \pm 0,05^{* * *}$ \\
\hline
\end{tabular}

Примітка: ${ }^{* *}-\mathrm{P}<0,01 ;{ }^{* * *}-\mathrm{P}<0,001$

Таким чином, в результаті проведених морфологічних досліджень можна зробити висновок, що лікарський засіб “Йодозол” при багаторазовому введенні не здійснює токсичного впливу на структуру і функцію життєво важливих органів і $є$ практично нешкідливим.

Дослідженням гематологічних показників крові щурів після орального введення 10-кратної дози “Йо- дозолу" встановлено зниження рівня гемоглобіну до $151,87 \pm 0,51$ г/л, гематокриту до $35,30 \pm 0,06 \%$,та еритроцитів 3 до $6,01 \pm 0,03 \mathrm{~T} / л$ і зростання кількості лейкоцитів до 9,91 $\pm 0,07$ г/л (табл. 3). За менших дозувань, середні гематологічні показники дослідних та контрольних груп тварин, не мали виражених відмінностей.

\section{Таблиця 3}

Гематологічні показники крові білих щурів на 31-шу добу досліду завивчення хронічної токсичності “Йодозолу", $\mathrm{M} \pm \mathrm{m}, \mathrm{n}=15$

\begin{tabular}{|c|c|c|c|c|}
\hline \multirow{2}{*}{ Показники } & \multicolumn{4}{|c|}{ Група тварин / доза препарату } \\
\hline & К (контроль) & Д1 (терапевтична) & Д2 (5-кратна) & Дз (10-кратна) \\
\hline Гемоглобін, г/л & $163,33 \pm 0,89$ & $159,27 \pm 0,51^{* * *}$ & $159,25 \pm 0,43^{* * *}$ & $151,87 \pm 0,51^{* * *}$ \\
\hline Еритроцити, Т/л & $7,45 \pm 0,12$ & $6,23 \pm 0,09^{* * *}$ & $6,02 \pm 0,03^{* * *}$ & $6,01 \pm 0,03^{* * *}$ \\
\hline Гематокрит, \% & $36,55 \pm 0,18$ & $36,59 \pm 0,08$ & $36,27 \pm 0,15$ & $35,30 \pm 0,06^{* * *}$ \\
\hline Лейкоцити, Г/л & $5,9 \pm 0,05$ & $6,35 \pm 0,11^{* *}$ & $7,58 \pm 0,11^{* * *}$ & $9,91 \pm 0,07^{* * *}$ \\
\hline
\end{tabular}

Примітка: ${ }^{* *}-\mathrm{P}<0,01 ;{ }^{* * *}-\mathrm{P}<0,001$

На відсутність токсичної дії за тривалого введення препарату “Йодозол” вказують також отримані біохімічні показники сироватки крові щурів. Виявлено, що при введенні 10-кратної дози препарату росте рівень лужної фосфатази - на 18,9\% ніж у щурів контрольної групи. “Йодозол” за всіх дозувань знижував рівень
АлАТ, одночасно достовірно підвищував рівень AcAT, що вказує на певні зміни в синтетичній функції печінки. Збільшення, але незначне порівнянно з контролем, кількості глюкози також мало місце у третій дослідній групі тварин (табл. 4).

\section{Таблиця 4}

Біохімічні показники крові білих щурів на 30-ту добу досліду при вивченні хронічної токсичності “Йодозолу”, $\mathrm{M} \pm \mathrm{m}, \mathrm{n}=15$

\begin{tabular}{|c|c|c|c|c|}
\hline \multirow{2}{*}{ Показники } & \multicolumn{4}{|c|}{ Групи тварин/доза препарату } \\
\hline & К (контроль) & Д1 (терапевтична) & Д2 (5-кратна) & Дз (10-кратна) \\
\hline Загальний білок, г/л & $53,99 \pm 0,08$ & $53,32 \pm 0,10^{* * *}$ & $51,91 \pm 0,13^{* * *}$ & $50,76 \pm 0,16^{* * *}$ \\
\hline Лужна фосфотаза, Од/л & $221,13 \pm 1,12$ & $236,73 \pm 0,84^{* * *}$ & $248,47 \pm 0,66^{* * *}$ & $262,87 \pm 0,92^{* * *}$ \\
\hline АлАТ, Од/л & $69,48 \pm 0,41$ & $64,84 \pm 0,13$ & $65,46 \pm 0,13^{* * *}$ & $64,16 \pm 0,04^{* * *}$ \\
\hline АсАТ, Од/л & $109,16 \pm 0,23$ & $111,93 \pm 0,11^{* * *}$ & $114,11 \pm 0,29^{* * *}$ & $119,55 \pm 0,26^{* * *}$ \\
\hline Глюкоза, ммоль/л & $3,1 \pm 0,03$ & $2,82 \pm 0,02^{* * *}$ & $2,95 \pm 0,04^{* *}$ & $3,57 \pm 0,08^{* * *}$ \\
\hline Сечовина, ммоль/л & $4,85 \pm 0,05$ & $4,51 \pm 0,06^{* * *}$ & $4,26 \pm 0,06^{* * *}$ & $5,05 \pm 0,05^{* * *}$ \\
\hline Креатинін, ммоль/л & $99,41 \pm 0,64$ & $103,79 \pm 0,68^{* * *}$ & $109,92 \pm 0,16^{* * *}$ & $120,12 \pm 0,19^{* * *}$ \\
\hline
\end{tabular}

\section{Висновки}

За довготривалого введення піддослідним тваринам новоствореного препарату “Йодозол” суттєвих відхилень у фізіологічному стані та поведінкових рефлексах не відзначено. Результати морфометрії внутрішніх органів та вивчення показників крові також не виявили суттєвих відхилень між дослідними та контрольними тваринами. Однак у сироватці крові щурів, які одержували максимальну, 10-кратно завищену дозу препарату, спостерігали відхилення показників білкового обміну та активності гепатоспецифіч- 
них ферментів: зростання загального білка, лужної фосфатази та аспартатамінотрансферази. Проте такі зміни параметрів мали короткотривалий та відновлювальний характер, що характеризує досліджуваний препарат як малотоксичний.

Перспективи подальших досліджень. Подальші дослідження препарату будуть спрямовані на розробку регламентів його застосування та проведення маркетингових заходів, спрямованих на продаж препарату на ринку лікарських засобів України.

\section{References}

Gutyj, B., Paska, M., Levkivska, N., Pelenyo, R., Nazaruk, N., \& Guta, Z. (2016). Study of acute and chronic toxicity of 'injectable mevesel' investigational drug. Biological Bulletin of Bogdan Chmelnitskiy Melitopol State Pedagogical University, 6(2), 174180. doi: $10.15421 / 201649$.

Gutyj, B.V. (2014). Doslidzhennia toksychnosti preparatu "Mevesel-iniektsiinyi" v khronichnomu doslidi [Study of toxicity of the drug "Mevsel-injection" in the chronic experiment] Naukovyi visnyk Lvivskoho natsionalnoho universytetu veterynarnoi medytsyny ta biotekhnolohii imeni S.Z. Gzhytskoho - Scientific Bulletin of the S.Z. Gzhytskiy Lviv National University of Veterinary Medicine and Biotechnology, 16, 2(59), 214-217 (in Ukrainian).

Katsaraba, O.A., Stefanyk, V.Y., Kostyshyn, Ye.Ye., Sachuk, R.N., \& Kulinich, O.V. (2018). Application of intrauterine aerosol preparation for the treatment of cows with postpartum complications. Scientific Messenger of Lviv National University of Veterinary Medicine and Biotechnologies. 20(87), 55-59. doi: $10.15421 /$ nvlvet8711.

Kosenko, M.V., Malik, O.G., \& Kotsyumbas, I.Ya. (1997). Toksikologichnij kontrol' novih zasobiv zahistu tvarin: metodichni rekomendacii [Poison control of new meansof protecting animals: guidelines]. Kiev (in Ukrainian).
Kotsyumbas, I.Ya., Malik, O.G., \& Patereha I.P. et al. (2006). Doklinichni doslidzhennja veterinarnih likars'kih zasobiv [Preclinical studies of veterinary medicinal products]. Lviv: Triadplus (in Ukrainian).

Lakin, H.F. (1990). Biometria [Biometrics]. Moskow: Vuszaichkola (in Russian).

Rozyn, D.H. (1964). Sovremennaia otsenka toksychnosty khlorproyzvodnukh uhlerodov zhyrnoho riada po heksenalovomu testu na belukh myshakh Farmakolohyia i toksykolohyia. [Current toxicity assessment of fatty chlorine derivatives of hexagonal test in white mice], 5, 613-614 (in Ukrainian).

Rylova M.L. (1964). Metodu yssledovanyia khronycheskoho deistvyia vrednukh faktorov sredu $\mathrm{v}$ eksperymente [in Russian].

Sachuk, R., Kulinich, O., \& Katsaraba, O. (2017). Eefficiency of the aerosol intrauterine preparation "Metrazol-bio" in endometritis in cows. Scientific Messenger of LNU of Veterinary Medicine and Biotechnologies. Series: Veterinary Sciences, 19(82), 110-113. doi: 10.15421/nvlvet8223.

Sachuk, R.M., Zhigaliuk, S.V., Tverdiy, V.M., Stravsky, Ya.S., Katyukha, S.M., Katsaraba, O.A. et al. (2018). Aerozolnyi preparat sefalosporynovoho riadu dlia profilaktyky ta likuvannia pisliarodovykh vnutrishnomatkovykh infektsii $\mathrm{u}$ tvaryn [Aerosol preparation of cephalosporin series for the prevention and treatment of postpartum intrauterine infections in animals]. Ukraine Utility model patent No. 127501 (in Ukrainian).

Stravsky, Y.S. (2017). Diahnostyka, likuvannia ta profilaktyka akusherskoi patolohii u koriv (metodychni rekomendatsii) [Diagnosis, treatment and prevention of obstetric pathology in cows (guidelines)]. Lviv (in Ukrainian).

Todoriuk, V.B., Hunchak, V.M., Gutyj, B.V., Gufriy, D.F., Hariv, I.I., Khomyk, R.I., \& Vasiv, R.O. (2018). Preclinical research of the experimental preparation "Ferosel T". Ukrainian Journal of Veterinary and Agricultural Sciences, 1(1), 3-9. doi: 10.32718/ujvas1-1.01. 